\title{
A new application of the Clark oxygen electrode
}

Citation for published version (APA):

Hemker, H. C. (1962). A new application of the Clark oxygen electrode. Biochimica et Biophysica Acta. Mucoproteins and Mucopolysaccharides, 60(3), 646-647. https://doi.org/10.1016/0006-3002(62)90885-5

Document status and date:

Published: 16/07/1962

DOI:

10.1016/0006-3002(62)90885-5

Document Version:

Other version

\section{Please check the document version of this publication:}

- A submitted manuscript is the version of the article upon submission and before peer-review. There can be important differences between the submitted version and the official published version of record.

People interested in the research are advised to contact the author for the final version of the publication, or visit the DOI to the publisher's website.

- The final author version and the galley proof are versions of the publication after peer review.

- The final published version features the final layout of the paper including the volume, issue and page numbers.

Link to publication

\footnotetext{
General rights rights.

- You may freely distribute the URL identifying the publication in the public portal. please follow below link for the End User Agreement:

www.umlib.nl/taverne-license

Take down policy

If you believe that this document breaches copyright please contact us at:

repository@maastrichtuniversity.nl

providing details and we will investigate your claim.
}

Copyright and moral rights for the publications made accessible in the public portal are retained by the authors and/or other copyright owners and it is a condition of accessing publications that users recognise and abide by the legal requirements associated with these

- Users may download and print one copy of any publication from the public portal for the purpose of private study or research.

- You may not further distribute the material or use it for any profit-making activity or commercial gain

If the publication is distributed under the terms of Article $25 \mathrm{fa}$ of the Dutch Copyright Act, indicated by the "Taverne" license above, 


\section{A new application of the Clark oxygen electrode}

The two current methods for measuring oxygen uptake in biochemical experiments, viz. the manometer and the oxygen electrode, each have their own advantages. This article describes an apparatus in which some of the advantages of both methods are combined.

In a polarographic experiment a series of additions can be made (see, e.g., ref. I), and the concurrent changes in oxygen consumption are registered immediately, but the amount of oxygen present in the medium limits the duration of the experiment and can restrict the possibilities of subsequent analysis of the reaction products. A further disadvantage of this method is that diffusion of $\mathrm{O}_{2}$ from the atmosphere into the reaction medium adds an unknown variable to the factors determining the final picture of oxygen uptake ${ }^{2}$.

In a manometric experiment only a very limited number of additions (usually not more than 2) can be made, and the rate of oxygen consumption is measured discontinuously. In this method, a large amount of oxygen can be consumed and this amount can be determined accurately. For this reason experiments in which the appearance of a product or the disappearance of a reactant is to be correlated with the oxygen uptake are best carried out manometrically.

In the course of an investigation on the effect of uncoupling phenols on the respiration of rat-liver mitochondria it was necessary to estimate rapidly and accurately the effect of a large series of phenol concentrations. The manometric method was too laborious, whereas the current "open" oxygen-electrode apparatus did not allow the testing of a sufficiently large series of phenol concentrations.

For these reasons, the closed apparatus described in Fig. I was developed. A CLARK ${ }^{3}$ oxygen electrode was used with a Philips PR 2IOO/A 2I recorder.

To obtain an accurate measurement of the oxygen uptake the following conditions must be fulfilled: (a) The temperature must be kept constant; (b) the medium in the vicinity of the membrane of the electrode must be refreshed continuously, in order to remain representative of the whole medium; (c) diffusion of oxygen from the atmosphere into the medium should not interfere with the measurement.

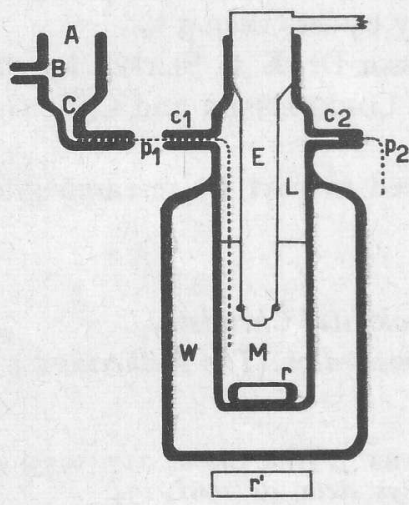

Fig. I. A closed-type oxygen-electrode apparatus. E, Clark oxygen electrode; M, reaction medium $(3 \mathrm{ml})$; L, air; W, water jacket; A-B-C, side-vessel; $c_{1}, c_{2}$ glass capillaries; $p_{1}, p_{2}$, plastic capillaries fitting airtight in the glass capillaries; $r, r^{\prime}$, stirring magnets. 
For our purpose, there were the additional requirements that more oxygen than that initially present in the reaction mixture should be made accessible without affecting the measurement, and a series of additions should be easily made.

Requirement (a) was achieved by circulating water from a thermostat bath through the jacket $W$, and requirement (b) by stirring with a magnetic stirring-rod system $\left(r\right.$ and $\left.r^{\prime}\right)$. Extra oxygen was introduced by allowing a volume of air $(L)$ to be trapped in the apparatus. When the stirring velocity was sufficiently high, whirling occurred at the water-air interface allowing the oxygen in both phases to remain in equilibrium.

Additions can be made either from a microburette or from the side-vessel shown in Fig. I. The microburette is to be preferred when various concentrations of one compound are to be tested, the side-vessel is the more useful when a number of compounds are to be added. In that case the solution to be added is pipetted into $\mathrm{C}$ through aperture $\mathrm{A}$, which is then shut by the finger, so that a small excess pressure maintained by an air pump connected to B pushes the liquid into the reaction medium. Practically quantitative addition can be achieved by rinsing the capillary $\mathrm{p}_{1}$ with a small amount of indifferent fluid. With practice, only a small amount of air is added when using the side-vessel in this way, and equilibrium is again established within $I_{5} \mathrm{sec}$. The end of the plastic capillary $\mathrm{p}_{2}$ is placed deep under the surface of paraffin oil. Addition of fluid through $\mathrm{p}_{1}$ results in the escape of some air through $\mathrm{p}_{2}$.

The general situation in this apparatus is essentially the same as in a Warburg flask, viz. an aqueous medium in which oxygen is consumed is in equilibrium with a gaseous phase. The differences are: (I) The oxygen concentration is measured in the liquid phase. The pressure of the gaseous phase is represented by the level of the paraffin oil in $\mathrm{p}_{2}$, but is not recorded. (2) A series of additions can be made. The use of a microburette enables the measurement of a concentration-inhibition curve of a single compound in the course of one experiment.

An estimation of the total amount of oxygen initially present is possible when the volumes of the liquid and the gaseous phase are known. This allows a calibration of the oxygen electrode, so that the $Q_{\mathrm{O}_{2}}$ can be calculated from the slope of the curve recorded, in the same way as is possible in experiments with the open oxygen electrode. Addition of $0.5 \mathrm{ml}$ of an indifferent fluid to respiring mitochondria in $3 \mathrm{ml}$ medium altered the recorded velocity by less than $5 \%$.

I am grateful to Professor Dr. E. C. Slater for discussions and advice, and to Messrs. H. De HaAn, H. J. Connelissen and C. G. G. Jasper for the construction of the apparatus.

This work was supported in part by research grant R.G. 6569 from the U.S. Public Health Service.

\section{Laboratory of Physiological Chemistry, University of Amsterdam, Amsterdam (The Netherlands)}

H. C. Hemker

1 B. Chance and G. R. Williams, J. Biol. Chem., 217 (1955) 383.

2 B. Hagihara, Biochim. Biophys. Acta, 46 (I96I) I34.

${ }^{3}$ L. C. Clark, R. Wolf, D. Granger and Z. Taylor, J. Appl. Physiol., 6 (I953) i89. 